\title{
RARE EARTH, TRACE ELEMENT AND STABLE ISOTOPE FRACTIONATION OF CARBONATITES AT KRUIDFONTEIN, TRANSVAAL.
}

\author{
Clarke, ${ }^{(1)}$ L.B.; Le Bas, ${ }^{(1)}$ M.J. and Spiro ${ }^{(2)}$ B. \\ (1) Department of Geology, University of Leicester, LE1 7RH, UK; (2) Isotope Geosciences Laboratory, British \\ Geological Survey, Keyworth, Nottingham, NG12 5GG, UK.
}

\begin{abstract}
The intrusive sequence of calcite carbonatites in the Proterozoic collapsed carbonatitic caldera at Kruidfontein shows fractionation of the trace and Rare Earth elements. The inclusion of two sovites from the immediately adjacent ( $4 \mathrm{~km}$ away) plutonic carbonatitic complex at Nooitgedacht extends this sequence. This fractionation can be correlated with Rayleigh fractionation of $\delta^{18} \mathrm{O}$ and $\delta^{13} \mathrm{C}$ such as is produced by a $\mathrm{H}_{2} \mathrm{O} / \mathrm{CO}_{2}$ molar ratio of $<0.5$ in a co-existing $\left(\mathrm{H}_{2} \mathrm{O}+\mathrm{CO}_{2}\right)$ vapour phase (Fig. 1). It is less well correlated with contamination by ground waters although some is likely to have taken place. It does not correlate with loss of isotopically light water during pressure reduction at the time of emplacement. For comparable values of $\delta^{180}$ in the intrusive carbonatites, the extrusive calcitic carbonatitic tuffs have lower $\delta^{13} \mathrm{C}$ values, which may be attributed to the loss of ${ }^{13} \mathrm{C}$ to the vapour phase. The unmineralized extrusive dolomitized carbonatitic tuffs have higher $\delta^{13} \mathrm{C}$ values. Contamination of the carbonatite by the Transvaal Sequence dolomite, which is the country rock, is not the prime cause for the dolomitization.
\end{abstract}

The carbonatitic fractionation from sovite to alvikite, taking only un-recrystallized samples, is best revealed by the Rare Earth elements, which show a three-fold overall increase (Fig. 2). This increase can be correlated with the increase in $\delta^{18} \mathrm{O}$ (Fig. 3). The early precipitation of pyrochlore caused La to act as a compatible element at first, but after the pyrochlore ceased to be precipitated, La became incompatible and the content remaining in the carbonatitic melt rose (Fig. 3). Other elements which behaved incompatibly are $\mathrm{Ba}$, $\mathrm{Zn}$ and $\mathrm{Mn}$.

Like $\mathrm{Nb}, \mathrm{Sr}$ behaved as a compatible element. Sr was strongly partitioned into apatite and calcite, both of which crystallized throughout the sequence. As a result, $\mathrm{Sr}$ steadily decreased with fractionation of the carbonatitic melt (Fig. 4). Recrystallization of carbonatite, usually marked by increase of $\delta{ }^{10} \mathrm{O}$, caused mobility particularly of the incompatible elements, with only lesser effects on elements such as $\mathrm{Sr}$.

A major late-stage event was the fluorite mineralization, and the progressive mineralization of both intrusive and extrusive carbonatites correlates with increasing values of $\delta^{18} \mathrm{O}$, but with ${ }^{13} \mathrm{C}$ remaining constant (Fig. 1). This also correlates well with hydrothermal alteration during equilibration with ground waters at low temperatures (c. $200^{\circ} \mathrm{C}$ ), and is taken to indicate that late-stage F-bearing fluids from the carbonatite mixed with ground water during the fluoritization.

The mineralization process, which affected the extensive carbonatitic tuffs preserved in the caldera and to a lesser extent the intrusive carbonatites, was accompanied by recrystallization of the carbonatites. The dolomitization and the mineralization are thought to be independent processes. 


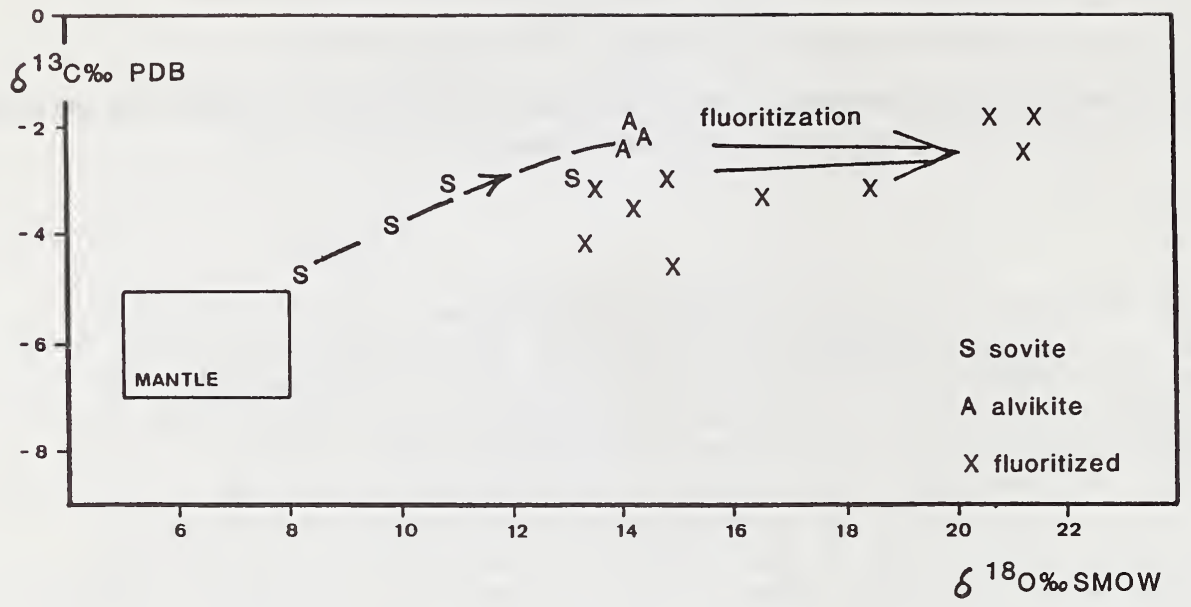

Fig. 1. Plot showing the fractionation of $O$ and $C$ isotopes with progressive crystallization from sovitic to alvikitjc carbonatites. Arrow shows direction of increasing fluoritization in samples, all recrystallized, containing from zero to $50 \%$ fluorite.



Fig. 2. Chondrite-normalized REE variation diagram showing the progressive increase in total REEs from sovite to alvikite.

Fluoritization caused a lowering of the LREE/HREEN ratio. (ICP data) 


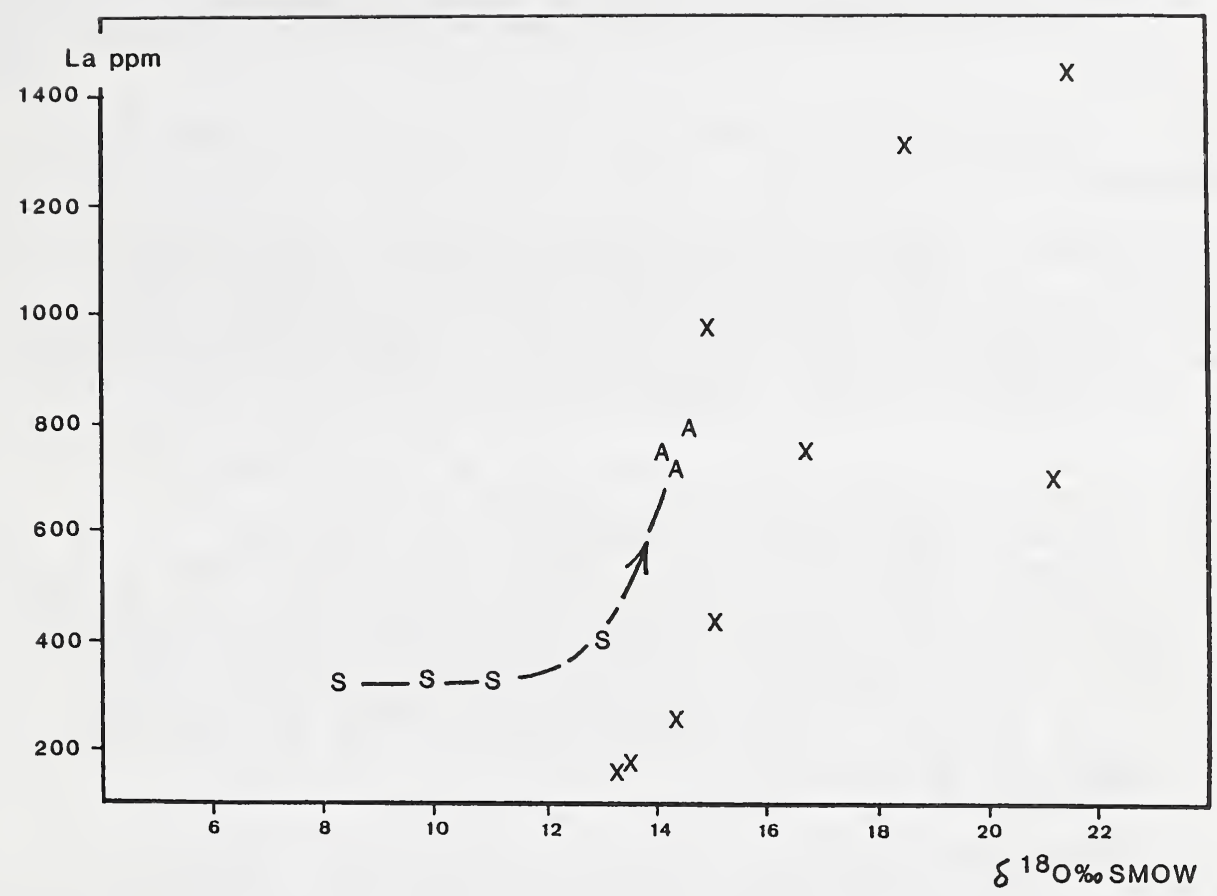

Fig. 3. Oxygen isotope - La plot showing the fractionation in the carbonatites ( $S$ and $A$ ) and the scatter caused by the fluoritization and recrystallization.

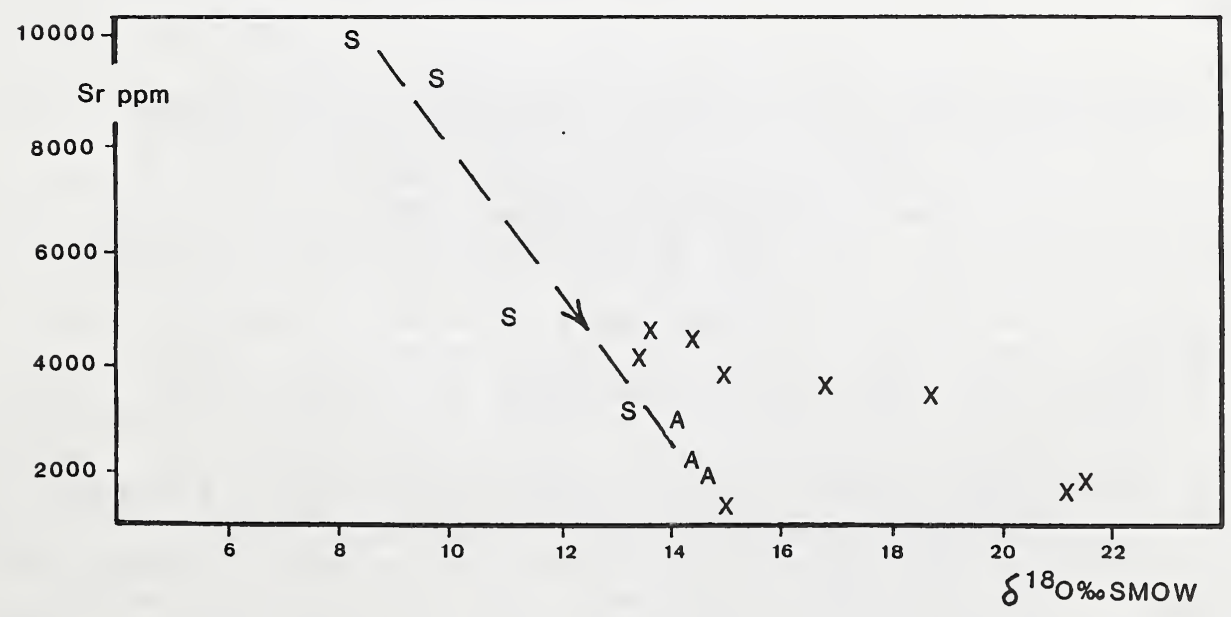

Fig. 4. Oxygen isotope - $\mathrm{Sr}$ plot showing the compatible behaviour of $\mathrm{Sr}$ during fractionation, and the dilution of $\mathrm{Sr}$ during late-stage fluoritization that is marked by the increase from c. 14 up to 22 per mille $\delta{ }^{18} \mathrm{O}$ 